\title{
PROMOTION OF MODEST CLOTHING BY A WESTERN RETAILER: INDICATION OF BRAND INCLUSIVENESS OR NEGATIVE IMPACT ON CONSUMER BASED BRAND EQUITY?
}

\author{
Aytak Amininajafi ${ }^{1}$ \\ ${ }^{1}$ Master of Science, Department of Marketing and International Management, Alpen-Adria University of Klagenfurt, \\ Austria
}

\begin{abstract}
This research was an investigation into promotion of modest clothing by a Western retailer meant to discover the effects of an inclusive marketing approach on consumer based brand equity. The purpose of the study was to observe possible differences between Muslim customers ' perception of consumer based brand equity in comparison to non-Muslim customers' perception. This survey-based study was descriptive, quantitative and comparative since it used a measurement scale to compare two groups of Muslims vs. non-Muslims. The sample was drawn from the population of H\&M customers who liked the H\&M Facebook page. The results of this research assist marketers in explaining and addressing the conflicting needs of different customer bases. One independent variable, religion, and one dependent variable, consumer based brand equity (comprised of five components, i.e. quality, preference, sustainability, social influence and leadership) have been included in the study. The related data was tested using MANOVA. The results revealed significant difference between Muslim and non-Muslim customers' perception of quality, preference, social influence and leadership as components of consumer based brand equity. However, there was no significant difference between the two groups' perception of sustainability as a component of consumer based brand equity.
\end{abstract}

Keywords:brand equity, consumer based brand equity, religion, sustainability

\section{INTRODUCTION}

Sustainable fashion industry marketing has many untapped areas and modest fashion along with attention to consumer's perception and consumer based brand equity are getting growing attention from different brands (e.g. Dolce and Gabbana, Hennes and Mauritz, etc.). Modest fashion basically targets modesty conscious individuals, e.g. Muslim women. As far as Muslims are concerned, the younger generation in particular, is becoming more fashion conscious as an increasing number of Muslim women choose to have more interactions in society to build a lucrative segment of the world's female consumer base. Yet, no research has studied consumer based brand equity in relation to modest clothing and the impact of an inclusive approach towards Muslims in comparison to non-Muslims (See e.g. Aaker [1], [2], [3]; Keller [31], [32]; Yoo and Donthu [65]; Baalbaki [5]). Muslims spent some 266 billion USD in 2013 on clothes and footwear. Not surprisingly, this figure is expected to rise up to 484 billion USD by 2019 [61]. After the $9 / 11$ catastrophe, more Muslim women are trying to dress fashionably [46]. Muslim clothing market makes up $11.9 \%$ of the global expenditure expected to reach 488 billion USD by 2019 . According to the latest facts and figures available from the year 2013 [46], Turkey, United Arab Emirates, Indonesia, and Iran, respectively, are countries with highest Muslim consumers clothing consumption. In addition, many western Muslim markets make use of global brand positioning to cross-sell to other modesty-conscious consumers. However, no matter how lucrative the Muslim market seems to be, fear of Islamic extremism associated with being a Muslim in general can impact the already established brand equity (brand loyalty and brand value specifically) of Western clothing retailers. Although this fear is not always easily tracked and documented, a brief analysis of comments generated on the online platform can well indicate that it is present.

As part of its marketing campaign to encourage sustainable behavior (by recycling clothes), H\&M published a short video featuring a Muslim hijab-wearing model as the voiceover said "Look chic." The video led to both positive and negative feedback. The current study has accordingly investigated the possible difference between Muslim and non-Muslim customers' perception of consumer based brand equity. In other words, at least some of the customers making the already established (non-Muslim) customer base were expected to show negative reaction to adoption of a more inclusive approach by the retailer from which they shop on a frequent basis. The research delved into promotion of modest clothing by addressing Muslim and non-Muslim subjects to clarify whether there is difference between Muslim and non-Muslim customers' perception of CBBE particularly after exposure to promotional content including a hijabi woman. Since little research has been conducted with focus on customer based brand equity perception and hijab-wearing women have been mostly ignored by most retailers, this study can partly describe the hijab-wearing customer perception of brand equity vs. nonMuslim customer perception. The results of this research are 
expected to help marketers understand the possibly conflicting needs of different customers. In addition, the results are expected to indicate whether promotion of modest clothing mostly functioning as an attempt to target hijab-wearing women still remains an issue when environmental sustainability and social responsibility are concerned. The research delves into promotion of modest clothing by addressing Muslim and non-Muslim subjects to clarify whether there is difference between Muslim and nonMuslim customers' perception of CBBE particularly after exposure to promotional content including a hijabi woman. The importance of this study is from different aspects (financial, cultural, social, environmental, etc.).

\section{REVIEW OF THE RELATED LITERATURE}

To understand the importance of a measurement scale which can determine the importance of a brand from the consumer perspective, concepts such as brand, brand equity and different measurement scales should bereviewed.

\subsection{Brand and Brand Equity}

Paragraph The concept brand is of central importance and has been covered by experts focusing on firms and their financial performance, customer research or a combination of both orientations. Almost all firms, especially those with stronger brand names strive to increase brand value in order to successfully attract, retain and satisfy customers. As far as the customers are concerned, they tend to purchase certain brands due to a number of different reasons which altogether partly/wholly guarantees their purchase by reducing the potential risks [8]. According to Kotler brand is an offer from a "known source" meant to distinguish the goods or services produced by a given seller or group of sellers from the competition [37]. Therefore, brand is considered to be a "promise" [20] by the selling party to deliver a particular service or product meeting certain quality requirements. In fact, brand adds other dimensions to a given service or product to the end of differentiating it from other similar goods or services [31]. As cited in Bengtsson and Ostberg[10], the American Marketing Association (AMA) provides the following definition for brand:

a name, term, design, symbol, or any other feature that identifies one seller's good or service as distinct from those of other sellers. The legal term for brand is trademark. A brand may identify one item, a family of items, or all items of that seller. If used for the firm as a whole the preferred term is trade name.

Comprehension of the gist of brand and brand equity facilitates understanding different conceptualizations. Many different definitions exist when it comes to brand equity. Farquhar [23] defines it as "added value endowed by the brand to the product" (cited in Farjam\&Hongyi [21]). Brand equity is also a market-centred intangible asset showing the relation between stakeholders and the company [16]. Aaker provides the following definition for brand equity [1]: "a set of assets and liabilities linked to a brand, its name and symbol, that adds to or subtracts from the value provided by a product or service to a firm and/or that firm's customers". Aakerbelieves that those brands enjoying considerable strength are more profitable in the end. In addition, brand equity takes influence from factors such as brand-name recognition, perceived quality, etc. [2]. Keller follows a customer based approach when it comes to brand equity. He studies CBBE based on a consumer psychology angle defining brand equity as the contradistinctive effect that brand knowledge has on how the consumer responds to promotional and marketing attempts. He believes that brand equity is indicative of the fact that the customer knows the brand and recalls the related brand associations. Thus, there is a distinctive effect of brand knowledge at work when the customer becomes subject to a marketing attempt and gives a response [31].

Myers makes mention of two approaches for estimating brand equity: firm-based (financial) and customer based (non-financial) approaches [48]. The firm-based approach assesses brand value from a monetary perspective (based on e.g. price index, profitability, etc.) focusing on the added value created for shareholders. In such approach, brands are deemed to be firm assets where brand strength, brand role and economic value-added are investigated. Analyzed from the firm's perspective, the financial value at work is acronymed as FBBE ([23]; [5]). The other perspective is customer based brand equity (CBBE) developed by Keller [31]. He believes that CBBE is influenced by how brand knowledge (comprised of brand awareness and brand image) affects consumer response to marketing attempts. Fournier is of the opinion that the value attached to a given brand as perceived by the customer also indicates the value that the organization offers to the customers [25]. This value is the reason the risks are minimized and the decision-making process is facilitated. Brand equity explains the consumer's choice between branded and unbranded products [65]. The experiences of customers with a brand's product/service influence their perceptions and eventually affect CBBE[38].

\subsection{Chronological Review of Brand Equity Scales}

A chronological review reveals that since the late seventies, different scales have been developed to measure brand equity. Srinivasan makes use of a multi attribute model and concentrates on customers. However, the model fails to provide explanations about brand effect [55]. In the nineties, Swait et al. talk about "equalization price" which is known as the utility of the product in monetary terms from the customer's perspective [57]. Within the same time span, Kamakura and Russell [29], investigate the concept of perceived quality and intangible value of brand. In the midnineties, Lassar et al. [42] based their proposed scale on Keller's work [31]. The proposed dimensions of their scale include performance, value, trustworthiness, social image and attachment. The concepts of confidence in a brand resulting in loyalty are important to their study. Leuthesser et al. [43] propose the halo effect idea relying on Keller's study [31]. The 2000s saw further attention to brand equity scale development. One of the most frequently quoted studies is the work of Yoo and Donthu [65], who based their research on the works of Aaker [1] and Keller [31]. Their 
proposed scale has brand loyalty, perceived quality, brand awareness and associations as its dimensions. Vazquez et al. also formulate a measurement scale with brand name and product utility as the dimensions [62]. Their study is based on the works of Kamakura and Russell [29] and Cobb Walgren et al. [18]. Washburn and Plank [63] made changes to Yoo and Donthu's work [65]. Ailawadi et al. [4] suggest use of revenue premium to measure brand equity basing their study on Keller's work [31]. De Chernatonyuses indepth interviews to build a performance measure. Their proposed dimensions include reputation, satisfaction and loyalty [22]. In the same year, Netemeyer et al. [49] based their study on works of Aaker [1] and Keller [31] to define the following dimensions: uniqueness, willingness to pay brand price premium, perceived quality and perceived value for cost. Christodoulides et al. [17] worked with online brands doing qualitative research proposing the following dimensions: emotional connection, online experience, trust, fulfilment and responsive service nature. Kocak et al. [35] made changes to the 22 item scale proposed by Vazquez et al. [62] and reached a 16 item scale. According to Baalbaki, the work by Lehmann et al [5] relied on Keller and Lehmann's previous research [33] to end in a suggestion based on a set of measures used for brand performance. The different dimensions used include comprehension, comparative advantage, interpersonal relations, history, preference and attachment. Built et al. [14] developed a scale including personality dimensions using Aaker's work [1]. They have used the same dimensions proposed by Aaker in his work of the early nineties. Davis et al. [19] based their measurement scale for logistic services on Keller's work [31] proposing the following dimensions: brand awareness, brand image and overall brand equity. Boo et al. [12] established a destination brand scale dependent on the theoretical works of Aaker [1] and Keller [31]. Their proposed dimensions include destination brand awareness, image, quality, value and loyalty. Atilganet. al(see [5]) use the works of Aaker [1] and Keller (1993) to introduce brand trust as a new dimension replacing brand awareness [66]. Given the chronological review, the theoretical framework chosen for the purpose of this study is a combination of the literature available on brand equity as conceptualized by Aaker [1] and Keller [31]. However, Keller's study [31] is more emphasized and serves as the basis for this research given the comprehensive approach used to maintain customer centricity. The study uses the items and dimensions covered in the customer based brand equity scale developed by Baalbaki [5] where consumer perception is highlighted. Thus, the following section details the works of Aaker [1], Keller [31] and Baalbaki [5].

\subsection{Aaker's Perspective vs. Keller's}

Aaker [3] introduces a model of brand equity comprised of the following components: brand loyalty, brand awareness, perceived quality, brand associations and other proprietary brand assets. The components of his model can be elaborated as follows: any firm hopes for its brand name to be associated with high quality from the customer's perception. Customers willingly pay the premium for quality products and services and purchasing quality products is always better justified. Keller [31], on the other hand, views brand equity from another perspective by emphasizing CBBE. Keller defines CBBE as "the differential effect of brand knowledge on consumer response to the marketing of the brand" [31]. Keller conceptualizes brand knowledge in connection with brand awareness and brand image based on the associative network memory model. The important element of the marketing mix, namely promotion, is assessed in an attempt to investigate the ways in which brand equity is affected. Keller's model of brand equity is the most detailed one which mostly concentrates on the consumer market[31], [32], [33]. A look at Keller's model, indicates four steps to build a strong brand with each step dependent on the former step's successful achievement (brand identity $\rightarrow$ brand meaning $\rightarrow$ brand responses $\rightarrow$ brand relationships). These steps are as follows: First, the right brand identity is established (to later result in brand awareness); Next, brand meaning is created based on the right brand associations; right after, positive responses are drawn forth; then the right relationship is established with customers. Successfully passing these steps also results in building six brand blocks. Therefore, the steps are dependent on salience, performance, imagery, judgments, feelings and resonance. The goal is to reach resonance where a harmonious relationship between customers and the brand is present. Kuhn et al. [40] believe Keller's model is also especial in that it concentrates on individual perceptions. All the product performance is very important, the features of the product which are not tangible matter more. The third step in Keller's model is indicative of different assessments and opinions which depend on different associations related to the brand. People make different judgments based on the product quality, superiority, credibility and consideration. As Baisya[7] declares, Keller's model was formed as a "comprehensive, cohesive, well-grounded, up-to-date and actionable" conceptualization; other constructions such as Young and Rubicam's model are closely related to Keller's work.

\subsection{Baalbaki's Scale}

A thorough review of different brand equity measurement scales reported previously affirms that the measurement scale developed by Baalbaki [5] is the only one resulting from qualitative research with consumer perception as the main focus of study. Therefore, the scale will be briefly reviewed in this section to determine its suitability as the basis for investigating the impact of more inclusive promotional strategies on CBBE. Baalbaki [5] claims that the bulk of brand equity related literature lacks empirical research which highlights consumer perception of brand equity. Thus, she conducts extensive qualitative research in an attempt to describe the intangible asset (i.e. brand equity) directly based on the consumer's mindset. Some of the faults she finds with other scales are as follows:

1- They simply rely on the works of Aaker [1] or Keller [31];

2- They are methodologically unreliable since they merely use students for testing and validating scales. 
Table -1: Customer based brand equity dimensions

(Baalbaki, 2012)

\begin{tabular}{|c|c|}
\hline Quality & $\begin{array}{l}\text { The reliability of (Brand X) is very high } \\
\text { (Brand X) is consistent in the quality it } \\
\text { offers } \\
\text { The performance of (Brand X) is very } \\
\text { high. } \\
\text { The quality of (Brand X) is extremely } \\
\text { high. } \\
\text { The functionality of (Brand X) is very } \\
\text { high. } \\
\text { (Brand X) has consistent quality. } \\
\text { (Brand X) performs consistently. } \\
\text { (Brand X) has an acceptable standard of } \\
\text { quality. } \\
\text { (Brand X) is well made. }\end{array}$ \\
\hline Preference & $\begin{array}{l}\text { (Brand X) would be my first choice. } \\
\text { I consider myself to be loyal to (Brand } \\
\text { X). } \\
\text { I will not buy other brands if (Brand X) is } \\
\text { available at the store. } \\
\text { I am committed to buying (Brand X). }\end{array}$ \\
\hline Sustainability & $\begin{array}{l}\text { (Brand X) is an environmentally safe } \\
\text { brand. } \\
\text { (Brand X) is an environmentally } \\
\text { responsible brand. } \\
\text { (Brand X) is a sustainable brand. } \\
\text { (Brand X) is a healthy brand. }\end{array}$ \\
\hline $\begin{array}{l}\text { Social } \\
\text { Influence }\end{array}$ & $\begin{array}{l}\text { (Brand X) improves the way I am } \\
\text { perceived by others. } \\
\text { (Brand X) would make a good impression } \\
\text { on other people. } \\
\text { (Brand X) would give its owner social } \\
\text { approval. } \\
\text { (Brand X) helps me feel accepted. }\end{array}$ \\
\hline Leadership & $\begin{array}{l}\text { (Brand } \mathrm{X} \text { ) would last a long time. } \\
(\text { Brand } \mathrm{X} \text { ) has good workmanship. } \\
(\text { Brand X) contributes something to } \\
\text { society }\end{array}$ \\
\hline
\end{tabular}

Given the purpose of this study and the literature available in this regard, five dependent and one independent variables have been defined to address the research problem. The independent variable is religion while the dependent variables are quality, preference, sustainability, social influence and leadership. The summation of these five components denotes customer based brand equity. The following section is a review of the pertinent variables.

\subsection{Research Variables}

Quality is the first dimension in the scale. As Zeithaml maintains [67], perceived quality refers to judgments passed by the customer on the product "excellence or superiority". This viewpoint highlights the necessity of stressing subjective evaluations by customers. Customers form perceptions of a given product quality against which the quality of products from different brands are judged [52]. Baalbaki [5] has tested the function of quality using nine items. The first three items were developed as a result of empirical research. These items were stated as follows: "The reliability of brand $\mathrm{X}$ is very high"; "Brand $\mathrm{X}$ is consistent in the quality it offers"; "The performance of Brand $\mathrm{X}$ is very high". The next two items were taken from Yoo and Donthu's study [65] stated as "The quality of brand $\mathrm{X}$ is extremely high" and "The functionality of Brand $\mathrm{X}$ is very high". Finally, the last four items "Brand X has consistent quality", "Brand X performs consistently", "Brand X has an acceptable standard of quality", "Brand X is well made" were all taken from Sweeney and Soutar's study [58].

The second dimension in the scale is preference. Brand preference means that the consumer selects one brand over others. Therefore, preference denotes making a choice [45]. As Baalbaki [5] clarifies, the notion of preference has been covered under the term loyaltyin the previously developed conceptualizations [1], [31]. She uses the items originating from these studies elaborated into Yoo and Donthu's study [65] as well as the item developed by Berry [11] under the term preference. The following items are used to assess preference in her study: "Brand $\mathrm{X}$ would be my first choice", "I consider myself to be loyal to brand X", "I will not buy other brands if brand $\mathrm{X}$ is available at the store", "I am committed to buying brand X". The first three items have been taken from Yoo and Donthu [65] while the last item has been taken from Berry [11].

The third dimension of the scale is sustainability. Recently consumers pay more attention to sustainable development and environmental issues. Accordingly, they are becoming more conscious about efficient use of resources meant for societal and economic advantages for all. According to Teodorovic[60], considering the increasing importance of marketing as a constitutional part of any successful responsible business, marketers are distinctly making every effort to integrate forcible sustainability components into marketing and branding strategies. Therefore, successful brand management calls for adequate brand development and the sustainability conscious environment. The current consumer is well informed and has access to real time information exchange sources, most of which are on the online platform. Thus, many companies have developed sustainability related marketing strategies in response to the modern consumer's environmental concerns. Brand value and brand equity are influenced by components of sustainability and are believed to affect brand knowledge to the extent that they would create a loyal relationship between the brand and customers. The major part of brand equity is built based on the customer's capability to identify and recall the brand in different settings and situations not to mention existence of positive associations all of which develop into brand knowledge [32]. Teodorovic [59] believes that being sustainably conscious is a source for creation of positive associations. In addition, the cost payable for a branded product owes to the brand awareness and brand image. Thus, when the consumer makes a purchase attempt, certain products come to mind due to brand awareness. On the other hand, certain emotions and perceptions are reinforced due to brand image. An "ecofriendly" or "green" product enjoys a sustainable brand 
image which in turn permits charging the "sustainability fee". Starbucks is the example of an eco-friendly brand whose customers pay the difference in cost compared to other similar products willingly due to its contribution to sustainability and social causes [41]. Implementing sustainability into the CBBE construct is challenging. In this sense, sustainability is viewed as a source for building stronger brands. As far as the consumers are concerned, the value they gain out of paying the sustainability fee is both from using sustainable products and from having a say in preserving the limited resources and the environment for future generations. Fashion theorists believe that sustainability will be an important part of the future fashion industry. From a historical perspective, use of recycled fabrics has mostly been dedicated to inferior purposes. However, recently this trend has been changing in favour of sustainable fashion industry. A number of chain brands are beginning to collect used clothes in their stores to be part of the sustainable fashion industry movement. The factor of sustainability was assessed using the following items: "Brand X is an environmentally safe brand", "Brand X is an environmentally responsible brand", "Brand $X$ is a sustainable brand" and "Brand $\mathrm{X}$ is a healthy brand" in Baalbaki's work [5].

The fourth component of the scale is social influence. Social influence has never been included in any brand equity scale. Analysis of consumer perceptions indicates that a branded service or product can affect the way in which the consumer is perceived by other individuals. This component explains how a branded product/service can result in social approval and create the feeling of being accepted by the majority for the owner. The items used by Baalbaki to assess social influence have been taken from Sweeney and Soutar's scale [58]. As Baalbaki [5] mentions, these items add value to the customer by creating a feeling of being accepted, creating a positive impression and gaining social approval. This dimension explains how purchase of a branded service or product assists the customer in obtaining social approval. The following items were used in her research to assess social influence: "Brand X improves the way I am perceived by others", "Brand X would make a good impression on other people", "Brand X would give its owner social approval", and "Brand X helps me feel accepted."

The last dimension known as leadership entails that the branded service or product is durable, enjoys a good design and plays significant role in being useful for society. Leadership is formed by two items from Sweeney and Soutar's study [58] and one from the scaled proposed by Brown and Dacin [13]. The items include "Brand X would last a long time", "Brand X has good workmanship" and "Brand X contributes something to society". Review of the literature related to the dependent variables, most particularly social influence and sustainability, paves the way for investigation into the independent variable and the concepts relating to that such as modest clothing. Therefore, the following section studies the concepts of modest clothing, the significance of religion for marketers and the lucrative business of cross-selling to modesty-conscious customers.

\subsection{Modest Clothing}

A brief look at the clothes collections of 2015 and the new collections of 2016 clearly indicates that the fashion industry has brought modesty back. Many giant retailers and some well-known designers have decided to start a new line of clothing targeting hijab wearing women in the first place. Dolce and Gabbana, for instance, has introduced a new line of abayas and hijabs; an introduction which has received a great deal of negative feedback as far as the non-Muslim customers are concerned. However, it still remains unknown which customer base is more lucrative or worth retainment: the new customer base who is now satisfied because of the more inclusive approach which is not excluding them any more in spite of their race, religion, ethnicity, etc. or the current customer base who are extremely opposed to any sort of inclusive approach which allows a modest way of clothing. Which option makes more sense: attracting new lucrative and promising customer bases or maintaining the already established customer base.Hoggard [28] claims that a degree of "nervousness" is involved in treating modest clothing as fashion. She brings the example of Baroness Warsi who wore a traditional dress to a formal meeting with David Cameron. She reiterates that the picture depicting the colourful outfit was not perceived as "fashion". Evidently, flee from the western way of dressing is considered a form of deconstruction.

As Bullock [15] explains in her review on Modest Fashion, the notion of hijab is gaining importance in academic research; however, this growing significance is far from treating "hijab as an object of curiosity or derision". In other words, hijab is rarely perceived as a normal subject of inquiry in research. Using the wording Modest Clothing, all modesty-conscious women including Christians, Muslims, Jews and even those women with no religion are studied. Bullock is of the opinion that many modesty-conscious women struggle to look stylish and fashionable while modesty is not treated as fashion. Lewis [44] explains how the ignorant behavior of the fashion industry towards modesty-conscious women has led to creation of a new sense of style. Many modesty-conscious entrepreneurs have built their own online stores whose products have appealed to women with different (religious) belief systems. Obviously, the online platform has greatly contributed to the imminence of weblogs and "interactive websites", as Bullock puts it, with women as active agents of the online modesty discourse. Dolce \& Gabbana recently gave rise to a tumult, following the launch of their new line of clothing which targets the Muslim customer base. The new line includes hijabs, head coverings and abayas. However, this attempt still does not make $D \& G$ a pioneer in this field given that previously DKNY, H\&M, Tommy Hilfiger and other famous brand names had made similar inclusive attempts [53].

\subsection{Inclusiveness}

From a financial perspective, investing in inclusive marketing strategies makes perfect sense given that Muslims are the fastest growing population [51]. According to a 
recent report, there is a huge demand for luxury items in Middle Eastern countries. Facts and figures indicate that this demand has seen an increase from 6.8 billion in 2014 to 8.7 billion in 2015. On the other hand, social networks and the online platform in general are paving the way for modest fashion to gain a stronger stand worldwide. The number of fashion bloggers and retailers who are targeting modesty conscious women is growing rapidly. Moda Operandi is another success story that sold a luxury necklace to a Middle Eastern customer in a London showroom for over \$ 400,000 [50]. To understand the general idea of inclusiveness, a brief definition is provided here. Inclusiveness is "part of the quality of mass market products and services, which makes them usable for the wider market" [9]. Development of a product which is intended for serving the broadest user group possible is known as "inclusive design". Therefore, those products and services which enjoy an inclusive design, i.e. user-centricity and modularity, are more appropriate for the mass market [9]. No study has so far investigated inclusive marketing in the sense meant in the current study. Inclusiveness has not been included in any measurement scale related to CBBE so far.

\subsection{Religion}

Consumption patterns and the purchase behaviors take influence from religion. Therefore, marketing experts must beware of the differences in cultural and religious preferences. Religion is defined as "belief in a divine or superhuman power or powers to be obeyed and worshiped as the creator(s) and ruler(s) of the universe" or "the expression of such belief in conduct and ritual" or any belief, worship or conduct system including a code of ethics and philosophy [36]. In the current study, religion is considered to be an independent variable. The customers can be Muslim or non-Muslim. However, non-Muslim in this sense, means not believing in the religion of Islam. Therefore, a non-Muslim can be an atheist or have a religion other than Islam.

\section{METHODOLOGY}

This empirical research is a quantitative survey-based study. It is also a comparative descriptive case study. From another perspective. In addition, it is an analysis and evaluation of a new CBBE scale. This research is an attempt to apply Baalbaki's scale developed in 2012 which focuses on consumers' perception in particular. While this research concentrates on fashion and modest clothing, Baalbaki's scale was based on cellular phones. However, it is confirmed that the scale is applicable to other categories of products and services as well. According to the related literature, this scale is believed to be one of the most newly developed ones where dimensions such as sustainability and social influence have been highlighted.

\subsection{Rationale, Theoretical or Conceptual}

\section{Background/Foundation}

The theoretical framework used for this study has been based on the conceptualizations of brand equity by Aaker
[1] and Keller [32] with a special look to the CBBE scale developed by Baalbaki [5]. According to Keller [31], CBBE is how brand knowledge affects consumer response to a marketing attempt [31]. Keller's model focuses on the consumption market and the final goal is to achieve brand salience. Nevertheless, Aaker and Keller's conceptualizations do not result in an applicable measurement scale [5] which justifies use of Baalbaki's five-dimension scale here with quality, preference, sustainability, social influence and leadership making up the dimensions (figure 1).

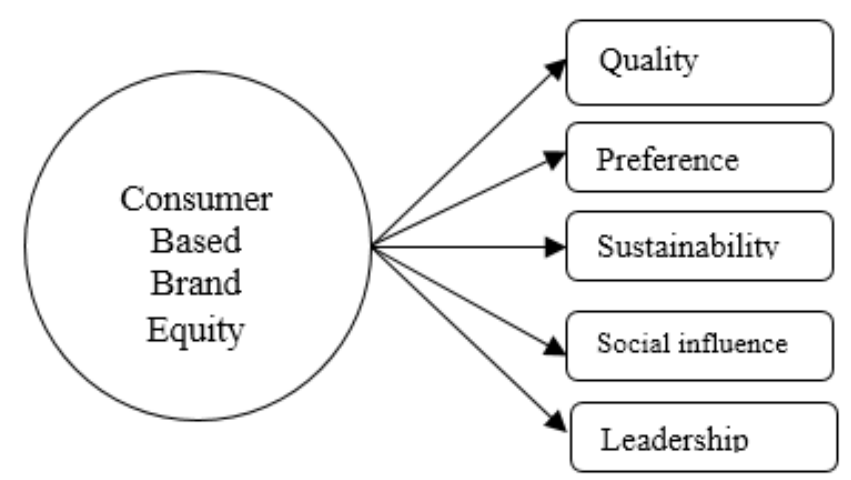

Fig -1: Dimensions of consumer based brand equity

\subsection{Research Design and Tools}

This quantitative research used a questionnaire approved by the experts in the field of marketing and brand management in particular. The online questionnaire was designed and filtered based on the viewpoints of the related experts relying on the measurement scale at hand with a special look to the theoretical framework proposed by Aaker [1] and Keller [32]. Therefore, the scale used was the same one Baalbaki [5] has proposed. The items quality, preference, sustainability, social influence and leadership were investigated. To do so, the online questionnaire using a 7point Likert scale with 1 indicating strongly disagree and 7 indicating strongly agree was employed. The brand to be discussed was Hennes \& Mauritz (H\&M) because the video "Closing the Loop" was published by this giant. Moreover, $\mathrm{H} \& \mathrm{M}$ is the first retailer to ever include a hijabi model in a promotional material, with a high view-count. The video has gone viral and has been viewed by millions of people having generated many comments for and against it. The video was mainly an attempt by H\&M to encourage (potential) customers to recycle clothes irrespective of rules, social norms, standards, gender, age, ethnicity, social background, religion, sexual orientation, nationality, etc., announcing there are no rules in fashion. H\&M's Facebook page enjoys $30,514,999$ likes last time checked (subject to change). Therefore, the population was considered to be unlimited and unknown (an indication of brand awareness). To do the research, a large number of female individuals from among those who liked H\&M page on Facebook were targeted so that at least 192 female individuals would respond. Selection of female only subjects is justified given that male 
individuals do not wear veil. The first part of the survey included demographics and assessed the customer's brand knowledge showing a promotional picture while the second part directed the participants to the link which played the video. Next, they were asked to provide answers to questions based on the promotional content they had observed. The data was gathered using a questionnaire administered to 192 Muslim and non-Muslim women on an online platform using the formula proposed by Morgan and Krejcie to determine the sample size. The results were compiled and data analysis was done using SPSS 20 software [39].

Based on the Cochran`s formula, the sample was decided to be at least 192 individuals, Muslim and non-Muslim women, within the age range of 18 to 54 , presumed to be fashion-conscious. The data was gathered using a structured questionnaire of twenty four items compiled from the available literature integrated into the questionnaire. Five variables were included for brand equity. A Likert-scale was used to measure CBBE. The items were based on the studies by Yoo and Donthu [65], Sweeney and Soutar[58], Berry [11], Brown and Dacin[13] and Baalbaki [5].

The questionnaire was divided in two sections, with the first mainly concerned with the demographics. At the end of the first section the participant was asked to look at a picture which depicts Mariah Idrissi, the first hijab wearing H\&M model, in modest clothing. Then the participant was asked if she had seen the picture before and further she was asked to which brand name she could relate the picture, if to any. These two questions were meant for a primary (rough) estimation of the customer's brand knowledge and brand awareness. The first section ended with a promotional video. The second part covered twenty four statements associated with one independent variable, consumer based brand equity, and five dependent ones, quality, preference, sustainability social influence and leadership. While the first nine statements were meant to test quality, the first four statements tested preference, the second group of four statements tested sustainability and the third group of four tested social influence. Leadership was tested based on the last three statements. Although it was expected that all the 192 completed questionnaires would be usable, only 186 were usable for the study. The study used three methods for data collection. It is considered to be a field study since expert opinion was sought to gain the information required for developing the questionnaire. The data was eventually collected using an online questionnaire. Part of the research was through documentation as the main form of basic research using books, scientific journals, research periodicals, etc. Last but not least, the online sources were used since they provide real time access to updated information.
Data preparation was done using Google Docs which allows exporting the data as an Excel file. The related file was then carefully studied to avoid cases of useless information. The data was further developed to be analyzed using SPSS software. In this research the independent variable was religion (defined as belief in a divine or superhuman power or expression of such belief in conduct [36]. The main emphasis has been on being a Muslim or not. The dependent variables tested in this study were dimensions of consumer based brand equity including: quality, preference, social influence, sustainability and leadership. The measurement scale used is especially useful because it is developed after a thorough analysis of all the direct and indirect methods used for assessing consumer based brand equity [5]. The scale is also based on Keller's comprehensive work. The variables are evidently assessed on a Likert scale by the participants. On the other hand, the study has one independent variable, religion, and one dependent variable, i.e. CBBE: a combination of five dependent variables in itself.

One of the tests used for this study was the validity test to investigate how effectively the related instrument can measure the defined target [34]. Validity is about the extent to which a measurement is successful in measuring the concept under discussion [6]. The validity test applied to the research tools, variables and the dimensions in question clearly states that the scale and content of the tools used in the study assesses the related variables precisely. Accordingly, the data gathered using the instrument should not be in excess of the requirements of the study and no part of the data gathered required for assessment of the variables should be ignored in any manner (ibid). Thus, the gathered data is expected to reflect the facts. The validity of the questionnaire was first confirmed based on the available literature and then it was sent to experts in the field for final approval. The related items required for each dimension were then determined and the questionnaire draft was finalized. To test the validity of the questionnaire, content validity was assessed first. Next, a couple of questionnaires were emailed to the university professors and experts of the field asking for their feedback. The questionnaire was finalized based on final approval of the developer of the measurement scale, i.e. Baalbaki whose scale has been used.

The reliability of data collected was measured using Cronbach's Alpha coefficient. The reliability test was conducted to check for inter-item correlation in each of variables in the questionnaire. Table 2 shows the Cronbach's Alpha coefficient for all the variables in the questionnaire obtained. The value of at least 0.70 is the basis of reliability for Cronbach alpha coefficient [47]. All responses collected had passed the reliability test. Meanwhile, for survey validity of questionnaires, content validity and construct validity were used. Content validity refers to the fitness of the contents of the measurement tool. The verification of 
content validity in social sciences depends on the professional knowledge of researchers. It is also possible to identify appropriate and relevant measurements from literature or employ the assistance of experts to determine the fitness of the contents to enhance content validity, and to ensure questionnaire effectiveness. The development of measurement tools in this paper is based on generalization of literature reviews (the resources have been included in relevant empirical literature). The questions were modified after interviews with experts. Therefore, the questionnaire in this paper is expected to carry a certain degree of content validity.

Table -2: Cronbach's Alpha Test Result

\begin{tabular}{|l|l|}
\hline Cronbach's Alpha $(\alpha)$ & \# Items \\
\hline 0.828 & 5 \\
\hline
\end{tabular}

The next test was the Kolmogorov Smirnov test run when the data collection was done. This test was meant to decide normality of the data [24]. Next, Data analysis was done based on descriptive statistics (mean and standard deviation) and multivariate analysis of variance (MANOVA) to test the hypotheses. Application of MANOVA helped with studying the interaction between variables.

\subsection{Research Hypotheses}

The research hypotheses used in this study were developed based on one independent variable (religion) and five dependent variables (quality, preference, sustainability, social influence, and leadership). The five dependent variables build consumer based brand equity. There is one main hypothesis which is further divided into five subhypotheses:

H.a. There is a significant difference between Muslim and non-Muslim customers' perception of consumer based brand equity.

H.a.1. There is a significant difference between Muslim and non-Muslim customers' perception of quality as a component of consumer based brand equity.

H.a.2. There is a significant difference between Muslim and non-Muslim customers' perception of preference as a component of consumer based brand equity.

H.a.3. There is a significant difference between Muslim and non-Muslim customers' perception of sustainability as a component of consumer based brand equity.

H.a.4. There is a significant difference between Muslim and non-Muslim customers' perception of social influence as a component of consumer based brand equity.

H.a.5. There is a significant difference between Muslim and non-Muslim customers' perception of leadership as a component of consumer based brand equity.

\section{DATA ANALYSES AND INTERPRETATION OF RESULTS}

This section covers presentation of the results and data analyses. The data has been summarized, codified, categorized and finally processed to the end of testing the research hypotheses. The data was studied using different statistical techniques on conceptual and experimental levels.

Table 3: Descriptive statistics for consumer based brand equity and its diminution based on religion

\begin{tabular}{|c|c|c|c|c|c|c|c|c|}
\hline & \multicolumn{8}{|c|}{ Religion } \\
\hline & \multicolumn{4}{|c|}{ non-Muslim } & \multicolumn{4}{|c|}{ Muslim } \\
\hline & $\sum_{\Sigma}^{\Xi}$ & 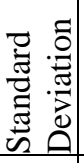 & $\begin{array}{l}\Xi \\
\Xi \\
\Xi \\
\Xi \\
\Xi\end{array}$ & 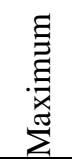 & $\sum_{\Sigma}^{\Xi}$ & 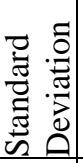 & $\stackrel{\Xi}{\Xi}$ & 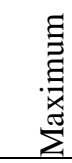 \\
\hline Preference & 2.71 & .62 & 1.33 & 4.56 & 4.03 & .70 & 2.33 & 5.00 \\
\hline Leadership & 2.54 & .69 & 1.00 & 5.00 & 3.88 & .68 & 1.50 & 4.67 \\
\hline Social Influence & 3.57 & .46 & 2.83 & 4.83 & 4.05 & .51 & 2.50 & 4.70 \\
\hline Quality & 3.48 & .91 & 1.50 & 5.00 & 4.02 & .56 & 3.00 & 5.00 \\
\hline Sustainability & 3.77 & .61 & 1.50 & 5.00 & 3.75 & .73 & 1.00 & 5.00 \\
\hline
\end{tabular}

The one-way multivariate analysis of variance (one-way MANOVA) is used to determine difference between independent groups considering more than one dependent variable. Analysing data using one-way MANOVA, suitability of the method for data analysis was decided and guaranteed. 


\subsection{KS Test: Data Normality}

As a general procedure, normality of the collected data is tested using the Kolmogorov Smirnov test. As detailed in the table below, the results of the KS test reveal that the significance level of all the variables is more than 0.05 . Therefore, all the research variables have normal distribution.

Table 4: Kolmogorov-Smirnov Test Results

\begin{tabular}{|l|l|l|l|l|}
\hline Variable & $\begin{array}{l}\text { Sample } \\
\text { size }\end{array}$ & $\begin{array}{l}\text { Test } \\
\text { Statistics } \\
\text { K-S }\end{array}$ & Sig & $\begin{array}{l}\text { Test } \\
\text { result }\end{array}$ \\
\hline Quality & 186 & 1.002 & 0.055 & normal \\
\hline Preference & 186 & 1.012 & 0.065 & normal \\
\hline Sustainability & 186 & 1.036 & 0.099 & normal \\
\hline $\begin{array}{l}\text { Social } \\
\text { Influence }\end{array}$ & 186 & 0.987 & 0.125 & normal \\
\hline Leadership & 186 & 1.059 & 0.099 & normal \\
\hline
\end{tabular}

\subsection{Homogeneity of Covariance Matrices}

MANOVA makes the assumption that the within-group covariance matrices are equal. If the design is balanced so that there are an equal number of observations in each cell, the robustness of the MANOVA tests is guaranteed. If the design is not balanced, the equality of covariance matrices should be tested using Box's M test. If this test is significant at less than 0.001, there may be distortion at the alpha levels.

Table 5: Box's Test of Equality of Covariance Matrices ${ }^{\mathrm{a}}$

\begin{tabular}{|l|l|}
\hline Box's M & 6.89 \\
\hline F & 1.124 \\
\hline Sig. & .345 \\
\hline
\end{tabular}

The Box's Test of Equality of Covariance Matrices checks the assumption of homogeneity of covariance across the groups using $\mathrm{p}<0.001$ as a criterion. There are no concerns - as Box's M (6. 8) was not significant, p (0.125) > (.001) indicating that there are no significant differences between the covariance matrices. Therefore, the assumption is not violated and Wilk's Lambda is an appropriate test to be used.

\subsection{Wilk's Lambda Matrices}

The following table indicates the MANOVA results using the Wilk's Lambda test. Using an alpha level of 0.05 , it is evident that the test result is significant, Wilk's Lambda amounts to $0.43, \mathrm{~F}(5,180)=46.62, \mathrm{p}<.001$. This significant $\mathrm{F}$ indicates that there are significant differences among the groups on a linear combination of the two dependent variables.
Table 6: Multivariate Tests ${ }^{\mathrm{a}}$

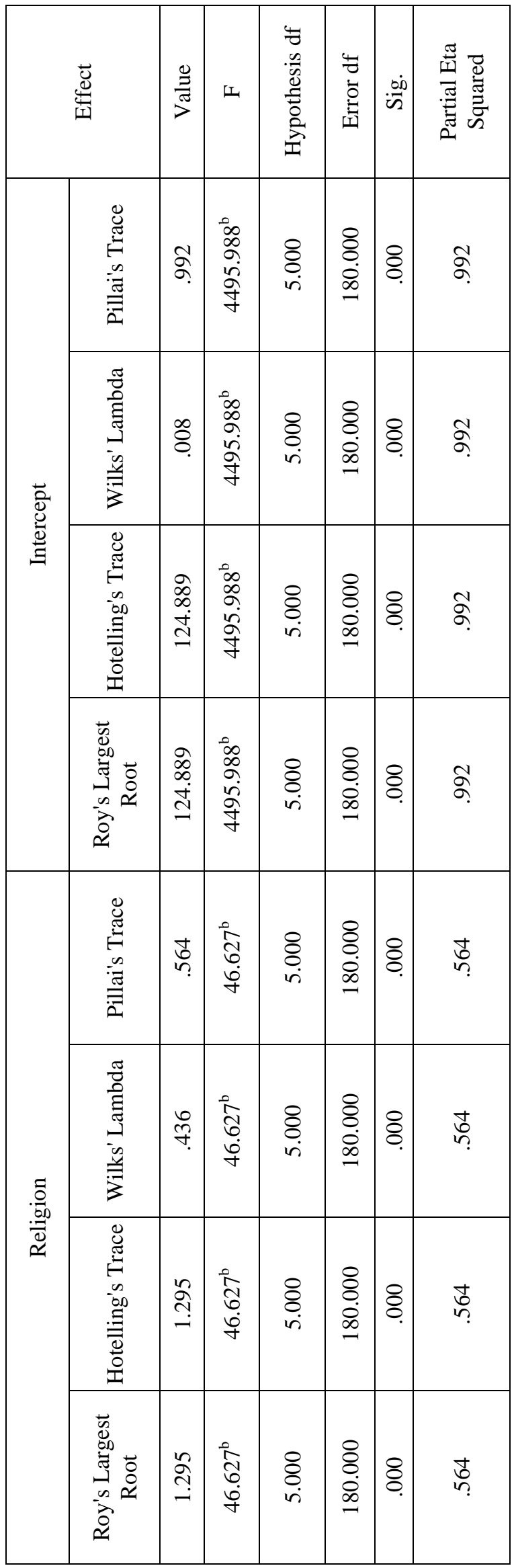




\subsection{Levene's Test of Equality of Error Variances}

The Levene's Test of Equality of Error Variances tests the assumption of MANOVA that the variances of each variable are equal across the groups. If the Levene's test is significant, this means that the assumption has been rejected - and data should be viewed with caution - or the data could be transformed so as to equalize the variances.

$$
\begin{aligned}
& H_{0}: \sigma_{1}{ }^{2}-\sigma_{2}{ }^{2}=0 \\
& H_{1}: \sigma_{1}{ }^{2}-\sigma_{2}{ }^{2} \neq 0
\end{aligned}
$$

The $p$-value of Levene's test is 0.000 ( $p<0.001$ ), so the null hypothesis of Levene's test is rejected. It is concluded that the variance in perception of quality as a dimension of CBBE for non-Muslim participants was significantly different from the same for Muslims. The assumption is confirmed for both dependent variables (The dimensions of consumer based brand equity, $\mathrm{p}>.05$ ).

Table 7: Levene's Test of Equality of Error Variances

\begin{tabular}{|l|l|l|l|l|}
\hline & $\mathrm{F}$ & $\mathrm{df1}$ & $\mathrm{df} 2$ & Sig. \\
\hline Leadership & .134 & 1 & 184 & .715 \\
\hline Social influence & .015 & 1 & 184 & .902 \\
\hline Preference & 5.041 & 1 & 184 & .026 \\
\hline Quality & 18.505 & 1 & 184 & .000 \\
\hline Sustainability & 1.926 & 1 & 184 & .167 \\
\hline
\end{tabular}

\subsection{MANOVA Test}

Given that the MANOVA result was significant, the univariate ANOVA results are examined. These tests were identical to the two separate univariate one-way ANOVA results which should have been performed if MANOVA had not been performed - provided that there had been no missing data. Given consumerbased brand equity and its dimensions, i.e. quality, preference, social influence and leadership test dependent variables are statistically significant and there are two levels or values of religion (non-Muslim and Muslim).Consumers' perception of sustainability as a component of consumer based brand equity test dependent variables are not statistically significant at two levels or values of religion (non-Muslim and Muslim).

\begin{tabular}{|c|c|c|c|c|c|c|c|}
\hline \multicolumn{6}{|c|}{ Univariate tests } & & \\
\hline \multicolumn{2}{|c|}{ 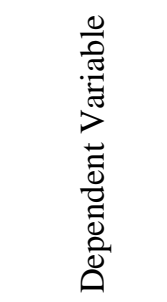 } & 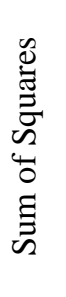 & 苚 & 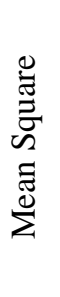 & I & $\dot{\infty}$ & 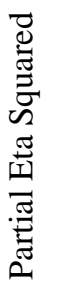 \\
\hline \multirow{2}{*}{ 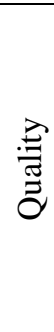 } & $\begin{array}{l}\tilde{\Xi} \\
\stackrel{\Xi}{\Xi} \\
\tilde{0}\end{array}$ & 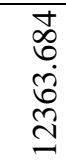 & 一 & 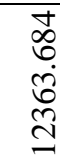 & $\begin{array}{l}\hat{0} \\
\hat{0} \\
\end{array}$ & 8 & గ্ర \\
\hline & $\stackrel{0}{0}$ & \begin{tabular}{l}
$\hat{\sigma}$ \\
$\dot{\sigma}$ \\
\multirow{\sigma}{0}{} \\
$\dot{v}$
\end{tabular} & $\underset{+}{+}$ & $\begin{array}{l}\text { ণิ } \\
\text { ㄱ }\end{array}$ & & & \\
\hline \multirow{2}{*}{ 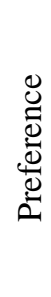 } & 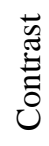 & $\begin{array}{l}\frac{n}{a} \\
\hat{a} \\
\text { aे }\end{array}$ & 一 & $\begin{array}{l}\frac{n}{\sigma} \\
\hat{\sigma} \\
\hat{\sigma}\end{array}$ & $\begin{array}{l}\bar{\sigma} \\
\hat{\sigma} \\
\hat{\sigma}\end{array}$ & 8 & $\frac{n}{n}$ \\
\hline & 氠 & $\begin{array}{l}\hat{\infty} \\
\stackrel{\infty}{+} \\
\underset{\forall}{+}\end{array}$ & $\infty$ & 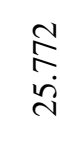 & & & \\
\hline \multirow{2}{*}{ 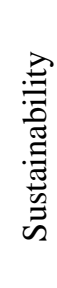 } & 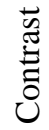 & $\begin{array}{l}\hat{O} \\
\stackrel{2}{0}\end{array}$ & 一 & $\begin{array}{l}\hat{尺} \\
\dot{0}\end{array}$ & $\begin{array}{l}\stackrel{+}{+} \\
n \\
\text { m }\end{array}$ & $\bar{b}$ & $\frac{a}{0}$ \\
\hline & 氠 & $\begin{array}{l}0 \\
\sim \\
\stackrel{2}{2} \\
\infty \\
\sim\end{array}$ & $\stackrel{+}{-}$ & $\begin{array}{l}\text { సે } \\
\text { ปे }\end{array}$ & & & \\
\hline \multirow{2}{*}{ 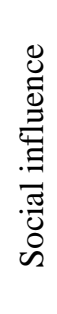 } & $\begin{array}{l}\overrightarrow{\tilde{E}} \\
\stackrel{\Xi}{\Xi} \\
\tilde{0}\end{array}$ & 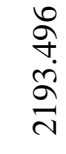 & 一 & 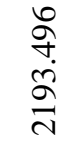 & $\begin{array}{l}\frac{\sigma}{\sigma} \\
\infty \\
\infty\end{array}$ & 8 & $\frac{m}{n}$ \\
\hline & 氠 & $\begin{array}{l}\infty \\
\text { ర్ } \\
\stackrel{8}{0} \\
\stackrel{\infty}{+}\end{array}$ & $\underset{+}{+}$ & $\stackrel{\vec{m}}{\overrightarrow{0}}$ & & & \\
\hline \multirow{2}{*}{ 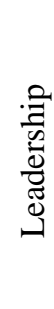 } & $\begin{array}{l}\tilde{\tilde{E}} \\
\stackrel{\Xi}{0} \\
0\end{array}$ & 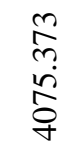 & - & 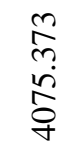 & $\begin{array}{l}n \\
\infty \\
0 \\
0\end{array}$ & 8 & $\frac{0}{n}$ \\
\hline & 氙 & 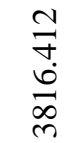 & $\stackrel{+}{\infty}$ & $\underset{\stackrel{+}{+}}{\stackrel{\nabla}{0}}$ & & & \\
\hline
\end{tabular}

Table 8: Tests of Between-Subjects Effects

H.a: There is a significant difference between Muslim and non-Muslim customers' perception of consumer based brand equity. 
The results of show that there is a significant difference between Muslim and non-Muslim customers' perception of consumer based brand equity: $(\mathrm{F}(5,180)=53.664, \mathrm{P}$ $=0.000$, ETA $=0.599)$. The difference indicates that consumer based brand equity is higher from the perception of Muslims compared to non-Muslims (Figure 2).

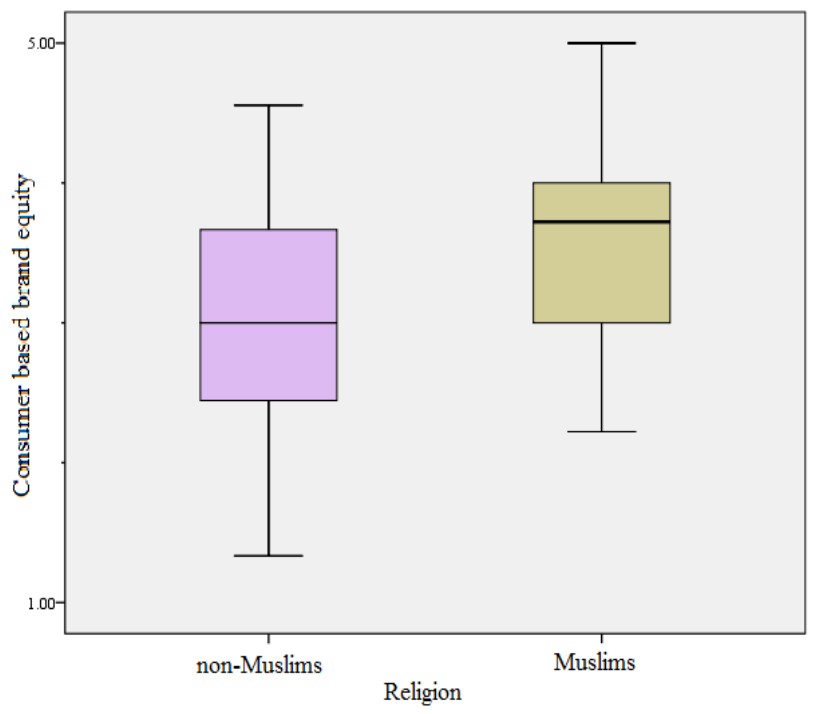

Fig 2: Comparison of Consumer Based Brand Equity Religion Side-by-Side.

H.a.1, there is a significant difference between Muslim and non-Muslim customers' perception of quality as a component of consumer based brand equity.

The results of variance test indicate that there is a significant difference between two groups of Muslims vs. non-Muslims in perception of quality as a component of consumer based brand equity: $(\mathrm{F}(5,180)=105.107, \mathrm{P}=0.000$, ETA $=$ $0.364)$. The information related to this section is illustrated in Figure 3 below for better comprehension. If the group binary levels are placed on the horizontal axis and the dependent variable quality is placed on the vertical axis, the estimated marginal means will be as follows:

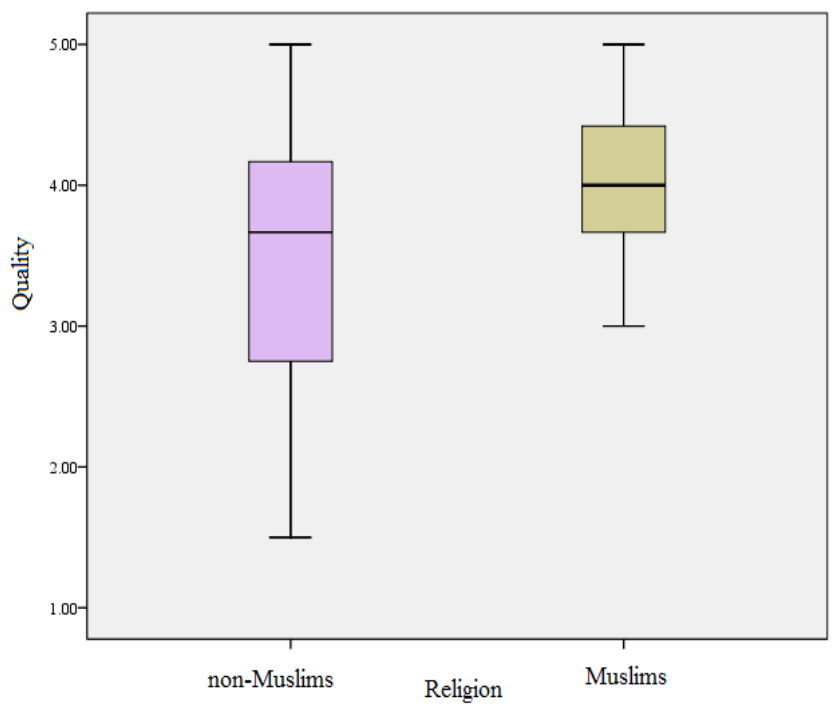

Fig. 3: Comparison of Quality Religion Side-by-Side.
H.a.2: There is a significant difference between Muslim and non-Muslim customers' perception of preference as a component of consumer based brand equity.

The results of variance test show significant difference between two groups as far as the component Preference is concerned. $(\mathrm{F}(5,180)=193.931, \mathrm{P}=0.000$, ETA $=0.513)$

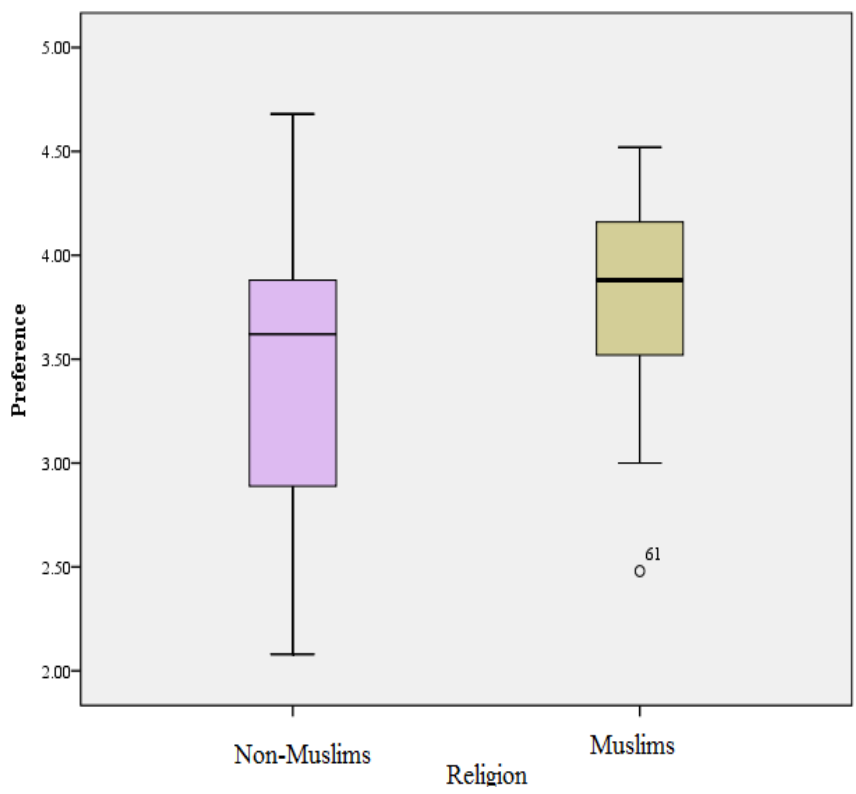

Fig. 4: Comparison ofPreference Religion Side-by-Side.

H.a.3: There is a difference between Muslim and nonMuslim customers' perception of sustainability as a component of consumer based brand equity.

The results of variance calculated show no significant difference between two groups as far as the component sustainability is concerned. $(\mathrm{F}(5,180)=3.540, \mathrm{P}=0.000$, $\mathrm{ETA}=0.019)$.

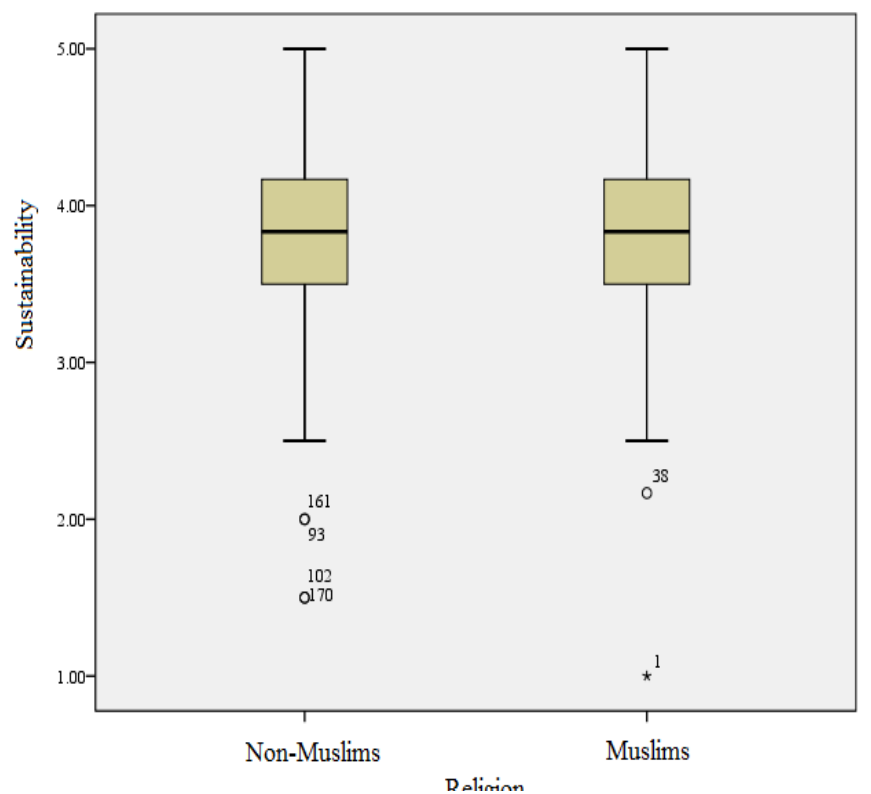

Fig. 5: Comparison of Sustainability and Religion. 
H.a.4: There is a significant difference between Muslim and non-Muslim customers' perception of social influence as a component of consumer based brand equity.

The results of variance test shows significant difference between two groups of Muslims vs. non-Muslims as far as the component social influence is concerned. $(\mathrm{F}(5,180)=$ 83.916, $\mathrm{P}=0.000, \mathrm{ETA}=0.313$ ).

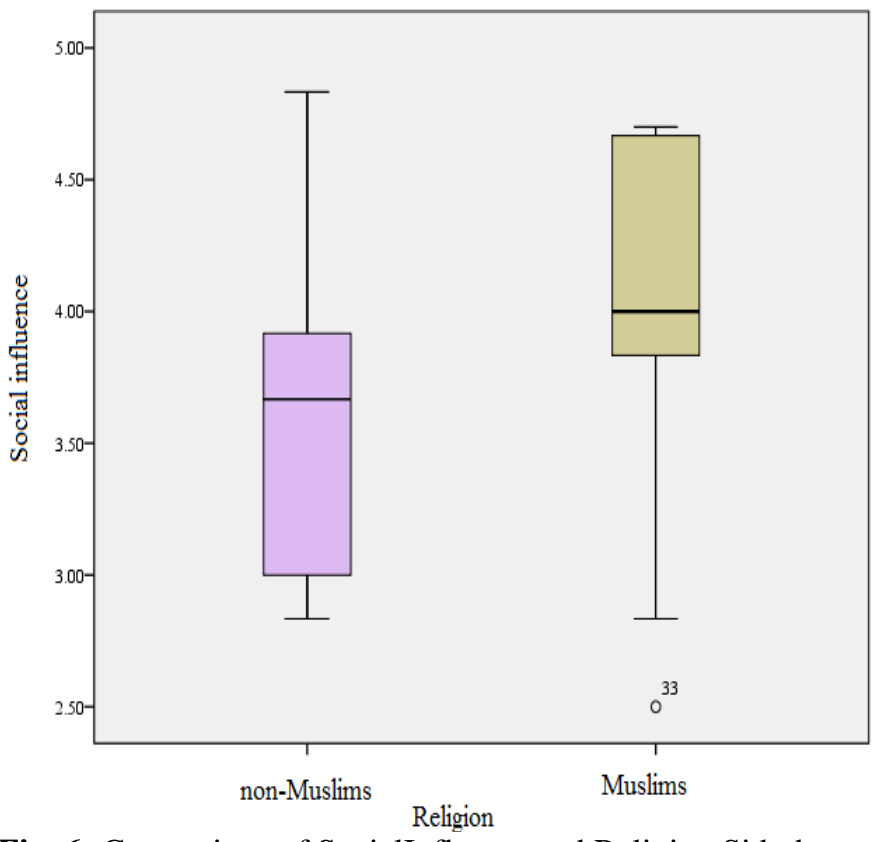

Fig. 6: Comparison of SocialInfluenceand Religion Side-bySide

H.a.5: There is a significant difference between Muslim and non-Muslim customers' perception of leadership as a component of consumer based brand equity.

The results of variance test show significant difference between the perceptions of two groups of Muslims and nonMuslims as far as the component leadership is concerned. (F $(5,180)=196.485, \mathrm{P}=0.000, \mathrm{ETA}=0.516)$

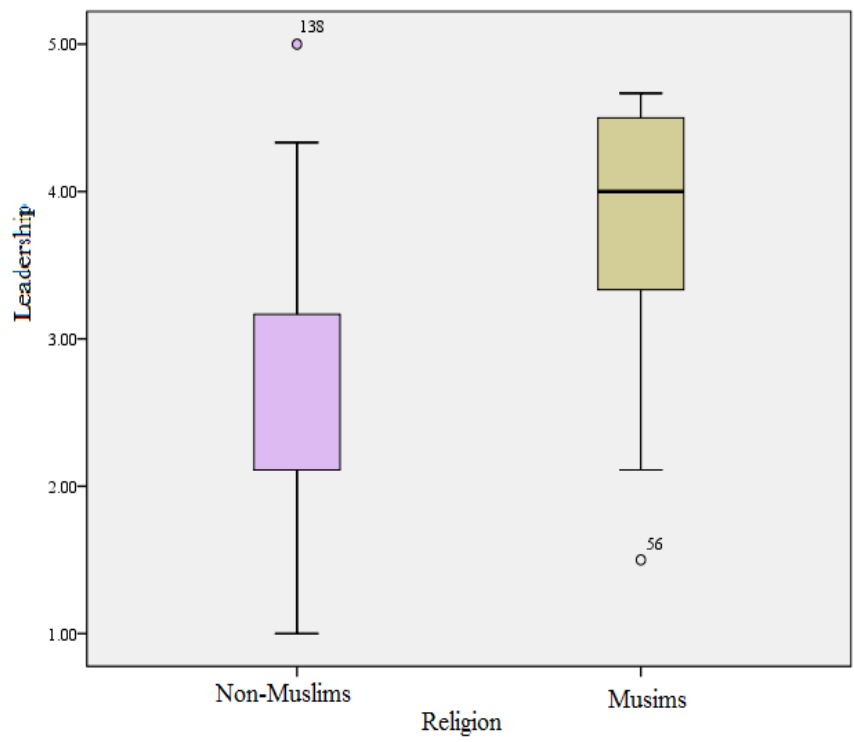

Fig. 7: Comparison ofLeadership Religion Side-By-Side.

\subsection{Discussions}

The findings of this study essentially relied on the questions included in the second section of the questionnaire. Nevertheless, part of the demographics section (first part of the questionnaire) had been dedicated to testing customer brand knowledge and brand awareness on a primary level. Given that brand equity takes influence from customers' perception and such perception is in turn affected by brand knowledge and brand awareness, the related questions assisted in recognizing the characteristics of the sample in question more effectively.

This research employed the CBBE measurement scale developed by Baalbaki to examine consumers' perception of five dimensions forming brand equity. The dimensions included quality, preference, social influence, sustainability, and finally leadership. This scale is the only one developed based on customers' perception. The independent variable was religion. The results confirm significant difference between Muslim and non-Muslim customers' perception of customer based brand equity. In fact, customer based brand equity is higher from the perception of Muslims compared to non-Muslims in the current case study as far as the selected and studied sample is concerned. Given that CBBE as the dependent variable had five main dimensions, it was influenced by all of the components of quality, preference, social influence, sustainability and leadership. The results confirm that there is a significant difference between the two groups in perception of quality since Muslims' perception of quality as a component of customer based brand equity is higher compared to non-Muslims. The same result is true as far as the components preference, social influence and leadership are concerned. On the other hand, it is also confirmed that there is a difference between Muslim and non-Muslims' perception of sustainability as a component of customer based brand equity; however, the said difference is not statistically significant. Therefore, all of the hypotheses are confirmed except for one. The rejected hypothesis is "There is a significant difference between Muslim and nonMuslim customers' perception of sustainability as a component of customer based brand equity." One possible argument for the lack of significance could be that sustainability adds value to the customer and contributes to preserving the environment. Environmentally friendly brands care about the environment and the customer simultaneously. The estimated marginal means of sustainability as a component of customer based brand equity is not significantly higher based on Muslim customers' perception. These results mean that the inclusive approach adopted as part of the marketing strategies of H\&M can be studied from different dimensions. The inclusive approach has resulted in difference in perception of CBBE between Muslims vs. non-Muslims. However, both groups show similar mentalities when it comes to sustainability. The results of this study have partially resolved the research problem in that at least it is determined that there is a significant difference between how Muslims and non-Muslims perceive customer based brand equity. However, it still remains unknown to what extent the issue of inclusiveness relates to customer based brand equity 
especially from the consumer's perception. On the other hand, assigning values to inclusiveness and deciding its relationship as an independent variable with dependent variables requires complicated statistical analyses beyond the scope of the current study.

Religion has been used as an independent variable in this study for effective comparison of Muslim vs. non-Muslim customers. In addition, in spite of the researcher's attempt to apply the best sampling method, it remains unknown if the resultant sample represents the population correctly. This is mainly a matter of concern because the number of Muslim participants is not equal to the number of non-Muslim customers. No research has to date covered the issue of CBBE from the perspective of the current study. Therefore, it is impossible to compare the results of this study to any other research. This research employed the CBBE measurement scale developed by Baalbaki [5] to examine consumers' perception of five dimensions forming brand equity. Given that $\mathrm{CBBE}$ is a multidimensional variable with five main components, it was influenced by quality, preference (i.e. the consumer selects one brand over others), social influence (the brand adds value to the customer since it helps them feel accepted and gain social approval), sustainability (the brand adds value for the customer by contributing to the environment) and leadership (the brand contributes something to society). There is a significant difference between the two groups in perception of quality since Muslims perceive quality as a component of consumer based brand equity in a more positive way compared to nonMuslims. The same result is true as far as the components preference, social influence and leadership are concerned. It was also confirmed that there is no significant difference between how Muslims and non-Muslims perceive sustainability as a component of consumer based brand equity. The estimated marginal means of sustainability as a component of consumer based brand equity was not significantly higher based on Muslim customers' perception.

\subsection{Implications}

It is asserted that attention to demographics to the end of effective and meaningful segmentation is a top priority for marketers. Marketing has to do with targeting (potential) customers based on previously defined characteristics of different groups. Currently many successful businesses are trying to make changes to or remain inclusive in their marketing strategies to respond to the needs of different (potential) customers irrespective of race, gender, religion, ethnicity, nationality, etc. Although inclusive marketing serves as a modern contrivance, at times it could lead to unexpected negative results. In other words, inclusive marketing should be applied with more care so that attracting new customers or appealing to potential customers would not cause loss of the already established brand equity. Although inclusive marketing flees from the already established conventions and stereotypes, brands need to take a conservative standpoint, at least partially. As far as the present case study was concerned, the promotional content which focused on the theme sustainability, produced positive and negative feedback in Muslim and non-Muslim customers. Not surprisingly, Muslims were satisfied with the inclusive content. However, the results were merely reported to be different meaning that the current study did not initially focus on how positively or negatively the results had been perceived by the two test groups in question. Referring to sustainability, the difference is not significant. To paint a socially and environmentally responsible picture of its business, every brand stands in need of incorporating sustainability into its branding and marketing strategies. The modern customer is well informed and makes mindful decisions based on the best value offering options.

\section{CONCLUSION}

A major motivation behind development of the current study was that the Muslim (potential) customer base opens the door to many new opportunities in the fashion industry. As specified before, fear of Islamic Extremism, mostly on the non-Muslim customers' part, associated with hijab wearing women is an obstacle before the majority of promotional attempts meant to increase brand inclusiveness and brand responsiveness, act more socially and environmentally responsible and aim for a lucrative outlook. The results of the current study revealed that the inclusive approach adopted by some giant retailers and well-known players of the fashion industry is not very welcome based on the nonMuslim customer base perception. However, not surprisingly, such inclusive approach has been hugely welcomed by the Muslim customer base to the extent that it has significantly affected the Muslim customer base brand equity. The results also stress once again cruciality of the environmental issues. When it comes to sustainability, it is the duty of every responsible brand to connect with all customers irrespective of gender, race, language, ethnicity, nationality, etc. On the other hand, the extent of migration occurring on a global scale is bringing about unexpected demographic and population changes on so many levels. The online platform is communicating such change rapidly. Thus, it is impossible to exclude certain demographics and include the traditionally approved customer bases. However, efficient customer retention in such a complicated demands and supply turmoil appears to be adopting a conservative tolerant approach. When different customer bases are directed to be tolerant of each other, a successful brand can respond to the needs and demands from both sides. In the case researched in this study, part of the comments generated by non-Muslims in response to the video Closing the Loop indicated fury and strong sarcasm from their side. New marketing and segmentation approaches are required to avoid such negative feedback from the already established customer base. All in all, most active players of the fashion industry are in this game relying on sound judgment and strong financial justification.

Another noteworthy point is that modesty is not specific to Islam. Christianity, Judaism, Buddhism, and many other religions promote modest clothing as well. Hamilton [27] mentions that there should be a basis for judgment (e.g. Bible in case of Christians) when it comes to modest clothing. Modest clothing is meant to cover nakedness regardless of whatever is temporarily in vogue. In other 
words, modest clothing is supposed to cover up nakedness to avoid unwanted (male) attention. According to Weddle Irons and Springer Mock [64], certain companies in USA respond to the demand for modest clothing (e.g. Modest Apparel USA) since some consumers find the clothes offered in random shops inappropriate. On the other hand, the "Modest is Hottest" movement believes that women can be modest and fashionable at the same time. As Wilson mentions, modesty clothing aims for sexual purity. Modest clothing attracts "quality guys" who are looking for more than bodily attractiveness in a woman. In this sense, a perfect example can be Audrey Hepburn who used to dress in a classy yet fashionable way. Modest clothing is supposed to buy women more respect and fight their objectification. Kamal [30] believes that fashion is not specific to nonMuslims emphasizing that the online platform has been assisting "religious expression" through fashion. Those hijab-wearing women who are interested in modesty and fashion at the same time can purchase online. Design of modest clothing can respond to the needs posed by Christians, Mormons, Jews and those interested in a more conservative style in addition to satisfying the needs of Muslims. For many young Muslims, it is impossible to afford high-end fashion products (e.g. Chanel shalwarKameez). However, at the same time a minority of Muslim "fashionistas" choose to wear that product. It is noteworthy that many recent fashion trends indicate crosscultural influences. The notion of "Modest Clothing" often connotes dressing in a dull, unfashionable and plain way. Nevertheless, as cited in Silverman, Levine believes many modesty-conscious non-Muslim women take part in "consumerism" [54]. Therefore, to remain modest, there is no need to sacrifice femininity and sense of style. All in all, there is a promising outlook for cross selling to other customers.

\subsection{Recommendations}

One way to achieve acceptable results from marketing to different customer bases is application of market segmentation strategies. Evidently, different consumer subsets can have common needs and demands. Responding to these demands based on the customer base characteristics could be done employing differentiated/undifferentiated methods pertinent to different product lines. As far as the current study is concerned, it is recommended that psychographic segmentation, cultural segmentation or segmentation based on demographics would be employed when it comes to inclusive marketing concentrated on sustainability. Psychographic segmentation concentrates on customers' AIOs, i.e. activities, interests and opinions [26]. Accordingly, the image the targeted customer is willing to project through their preferred lifestyle and activities are taken into account to study the already established or potential purchase decisions. Another effective way of segmentation is categorizing markets based on the cultural differences. Cultural segmentation facilitates marketing to and communicating with defined cultural communities [56]. It is also advisable to segment according to demography. Such segmentation is done with respect to perceived product benefits or defined variables (e.g. gender, religion, educational status, etc.). In line with this, it is recommended that more inclusive marketing approaches be tested in those contexts where Muslim customer population density is higher or generally the levels of tolerance or acceptance are higher.

\subsection{Suggestions for Further Studies}

The same study might be conducted using an only male sample or on a sample including both male and female participants using the scale developed by Baalbaki. In fact, modest clothing is not specific to women. Nevertheless, men do not wear veil. It is expected that asking male opinion about fashionable modest clothing would provide enlightening results given that in many Muslim cultures, the male individuals pay for the clothing purchased by/for female individuals in the family. In addition, male judgment is valued and taken into account by female individuals. The kind of research that would study different ethnic groups and religions would also be a very interesting one. Conducting a qualitative study with a group of fashionconscious and/or sustainability-conscious bloggers on a small scale and with customers on a larger scale can yield valuable results to the extent that it could lead to improvement of the sustainability dimension of the scale used in this study. The results from such studies may confirm that improving sustainability-consciousness and brand sustainability in general can serve as an effective practicable means of enhancing brand equity. The current study failed to measure inclusiveness due to the subjective nature of this concept. Therefore, religion was used as the independent variable to investigate its correlation with consumer based brand equity. This study could be improved if the concept inclusiveness could be measured and its effect on consumer based brand equity components could be detailed. The promotional and marketing attempts by other brand names could produce interesting results. Another untapped area is cross-selling to modesty conscious customers.

\section{REFERENCES}

[1] Aaker, D. A. (1991). Managing Brand Equity. New York: Free Press.

[2] Aaker, D. A. (1995). Building strong brands. New York: Free Press.

[3] Aaker, D. A. (1996). Measuring Brand Equity across Products and Markets. California ManagementReview, 38 (3), 102-20.

[4] Ailawadi, K. L., Lehmann, D. R. and Neslin, S. (2003). Revenue premium as an outcomemeasureof brand equity. Journal of Marketing, 67(4), 1-17.

[5] Baalbaki, S. (2012). Consumer perspective of brand equity measurement: a new scale (Unpublished Doctoral Dissertation, University of North Texas, Texas, United States). Retrieved fromhttp://digital.library.unt.edu/ark:/67531/metadc1 15043/m2/1/high_res_d/dissertation.pdf

[6] Babbie, R. (1989). The practice of social research. Minnesota: Wadsworth Publishing Company. 
[7] Baisya, R. K. (2013). Branding in a competitive marketplace. India: Sage Publications.Retrieved from https://books.google.com/books?id=FN2GAwAAQB AJ\&pg=PA92\&lpg=PA92\&dq=\%22comprehensive, +cohesive,+well-grounded,+up-to-

date\%22\&source=bl\&ots=P7I6Y_LltC\&sig=IKfE8L xlbZwRZebqHix4YmIlP1Q\&hl=de\&sa=X\&ved=0ah UKEwijx-

i6gsvLAhUIQJoKHSVvCsMQ6AEIHTAA\#v=onepa ge\&q= $\% 22$ comprehensive $\% 2 \mathrm{C} \% 20$ cohesive $\% 2 \mathrm{C} \% 2$ 0well-grounded $\% 2 \mathrm{C} \% 20$ up-to-date $\% 22 \& \mathrm{f}=$ false

[8] Barwise, P. (1993). Introduction to the special issue on brand equity. International Journal of Research in Marketing 10(1), 3-8.

[9] Belitz, S., Ranta-aho, M. and Äijö, R. (2007). User centered design of communication services. In T.O. Korhonen and A. Ainamo (Eds.), Handbook of product and service development in communication and information technology, (45-78). New York: Springer Science \& Business Media.

[10] Bengtsson, A. \&Ostberg, J. (2006). Researching the cultures of brands. In R. W. Belk (Ed.), Handbook of qualitative research methods in marketing (pp. 8394). USA: Edward Elgar Publishing Limited. Retrieved from https://books.google.at/books?id=wikcliAq_SMC\&pr intsec $=$ frontcover $\& \mathrm{hl}=\mathrm{de} \# \mathrm{v}=$ onepage $\& \mathrm{q} \& \mathrm{f}=$ false

[11] Berry, L. (2000). "Cultivating service brand equity". Journal of the academy of marketing science, 28(1), 128-137.

[12] Boo, S., Busser, J. and Baloglu, S. (2009). A model of customer-based brand equity and its application to multiple destinations. Tourism Management, 30, 219230.

[13] Brown, T. J. and Dacin, P. A. (1997). "The company and the product: corporate associations and consumer product responses". Journal of marketing, 61. 68-84.

[14] Built, I., de Chernatony, L. and Martinez, E. (2008). A cross-national validation of the consumer-based brand equity scale. Journal of Product and Brand Management, 17(6), 384-392.

[15] Bullock, K. (2015). Book review: Modest fashion: styling bodies, mediating Faith by R. Lewis (Ed.). Journal of International Women's Studies, 16(2), 399400. Retrieved from: http://vc.bridgew.edu/jiws/vol16/iss2/26

[16] Capron, L., and Hulland, J. (1999). Redeployment of brands, sales forces, and general marketing management expertise following horizontal acquisitions: A resource-based view. Journal of Marketing, 63(2), 41-54.

[17] Christodoulides, George., Leslie de Chernatony, Furrer, O., and Abimbola, T. (2006). Conceptualising and measuring the equity of online brands.Journal of MarketingManagement, 22(7/8), 799-825.

[18] Cobb-Walgren, C. J., Ruble, C. and Donthu, N. (1995). Brand equity, brand preference, and purchase intent. Journal of Advertising, 24(3), 25-40.

[19] Davis, D. F., Golicic, S. L. and Marquardt, A. (2009). Measuring brand equity for logistics services. The
International Journal of Logistics Management, 20(2), 201-212.

[20] Davis, S. M. (2002). Brand Asset Management. CA: Jossey Bass.

[21] Farjam, X and Hongyi, X (2015). Reviewing the concept of brand equity and evaluating consumerbased brand equity (CBBE) models International Journal of Management Science and Business Administration, 1(8), 14-29.

[22] deChernatony, L. (2006). From brand based vision to brand evaluation: The strategic process of growing and strengthening brands. 2nd ed. Burlington: Elsevier Ltd

[23] Farquhar, Peter H. (1989). Managing brand equity. Marketing Research, 1 (September), 24-33. Assets, Report 91-119, Marketing Science Institute, Cambridge, MA.

[24] Feinstein, C. H. and Thomas, M. (2002). Making history count: a primer in quantitative Methods for historians. U.K: Cambridge University Press.

[25] Fournier, S. (1998). Consumers and their brands: developing relationship theory in consumer research. Journal of Consumer Research 24(4), 343-373.

[26] Gunter, B. and Furnham, A. (2014). Consumer profiles (RLE consumer behavior): an introduction to psychographics. London: Routledge.

[27] Hamilton, J. W. (2001). Genesis: a study of the beginning. California: Lulu Press Inc. Retrieved from https://books.google.at/books?id=q8nrAgAAQBAJ\& printsec $=$ frontcover $\& \mathrm{hl}=\mathrm{de} \# \mathrm{v}=$ onepage $\& \mathrm{q} \& \mathrm{f}=$ false

[28] Hoggard, L. (2013). Modesty regulators: Punishing and rewarding women's appearances in mainstream media. In R. Lewis (Ed.), Modes fashion: Styling bodies, mediating faith (175-189). New York: Tauris. Retrieved from https://books.google.at/books?id=aI8AAwAAQBAJ $\& p g=$ PA53\&lpg=PA53\&dq=reina+lewis+wiki\&sour ce $=$ bl\&ots $=$ oHwMjSOtrd\&sig $=u c 0 A j C 1 C h F 4 \_X F k l t$ JCfibqBFMI\&hl=de\&sa=X\&ved=0ahUKEwjo2przg YLKAhXJ1iwKHd_uBwIQ6AEIYjAJ\#v=onepage\& $\mathrm{q}=$ reina\%20lewis\%20wiki\&f=false.

[29] Kamakura, W. and Russell, G. (1993). Measuring brand value with scanner data. International Journal of Research in Marketing, 10(1), 9-22.

[30] Kamal, R. (2014). Islamic dress and fashion in the United States. In Y.V. Haddad \&J.I. Smith (Eds.), The Oxford handbook of American Islam (426-438). Oxford: Oxford University Press. Retrieved from https://books.google.at/books?id=5y_cBAAAQBAJ\& printsec $=$ frontcover $\& d q=T h e+O x$ ford + handbook + of + American+Islam\&hl=de\&sa $=X \& v e d=0$ ahUKEwiY yeWyzP3JAhUKVRQKHXCNAgwQ6AEIKzAA\#v= onepage $\& \mathrm{q}=\mathrm{The} \% 20$ Oxford $\% 20$ handbook $\% 20$ of $\% 2$ 0 American $\% 20$ Islam \&f=false.

[31] Keller, K. L. (1993). Conceptualizing, measuring, and managing customer- based brand equity. Journal of Marketing, 57(1), 1-22.

[32] Keller, K. (2003). Strategic brand management: building, measuring and managing brand equity (2nd Ed.). New York: Prentice Hall. 
[33] Keller, K. and Lehmann, D. R. (2003). How do brands create value.Marketing Management, 12(3), 26-31.

[34] Kerlinger, F. N. (1973). Foundations of behavioral research. New York: Holt, Rinehart \& Winston

[35] Kocak, A., Abimbola, T. and Ozer, A. (2007). Consumer brand equity in a cross-cultural replication: an evaluation of a scale. Journal of Marketing Management, 23(1/2), 157-173.

[36] Koenig, H. G., McCullough, M. E., and Larson, D. B. (2001). Handbook of religion and health. London: Oxford University Press. Retrieved from https://books.google.com/books?id=h8F3OmblmH4C $\& p g=\mathrm{PA} 18 \& \mathrm{dq}=\% 22$ religion + is + defined + as $\% 22 \& \mathrm{hl}$ $=$ de $\& s a=X \& v e d=0 a h U K E w j j 3 a f H h s \_L A h V G s x Q K$ He41At8Q6AEIJjAB\#v=onepage $\& \mathrm{q}=\% 22$ religion $\% 2$ 0is $\% 20$ defined $\% 20$ as $\% 22 \& \mathrm{f}=$ false

[37] Kotler, P. (2001). Marketing management:the millennium edition (10th Ed.). NJ: Prentice Hall. Retrieved

fromhttp://www.perspectiva.md/ro/files/biblioteca/Ko tler-

Marketing\%20Management\%20Millenium\%20Editio n.pdf

[38] Kotler, P. \& Keller, K. L. (2006). Marketing management. NJ: Pearson Education.

[39] Krejcie, R.V., \& Morgan, D.W., (1970). Determining Sample Size for Research Activities. Educational and Psychological Measurement, 30. 607-610.

[40] Kuhn, K. L., Alpert, F., Pope, N. K. L. (2008). An application of Keller's brand equity model in a B2B context. Qualitative Market Research: An International Journal,11(1), 40-58. Retrieved from http://dx.doi.org/10.1108/13522750810845540t.

[41] Laasch, O. (2015). Marketing and communication: in stakeholder goodwill. In O. Laasch and R.N. Conaway (Eds.), Principles of responsible management: local sustainability, responsibility and ethics (365-400). Canada: Cengage Learning. Retrieved from https://books.google.at/books?id=0uLKAgAAQBAJ \&printsec $=$ frontcover $\& \mathrm{hl}=\mathrm{de} \# \mathrm{v}=$ onepage $\& \mathrm{q} \& \mathrm{f}=$ false

[42] Lassar, Walfried, Banwari Mittal, and Sharma Arun (1995), "Measuring Customer-Based Brand Equity," Journal of Consumer Marketing, 12 (4), 11-19.

[43] Leuthesser, L., Kohli, C.S. and Harich, K.R. (1995).Brand equity: the halo effect measure. European Journal of Marketing, 29(4), 57-66.

[44] Lewis, R. (2013). Introduction: mediating modesty. In R. Lewis (Ed.), Modes fashion: Stylingbodies, mediating faith (1-16). New York: Tauris. Retrieved from

https://books.google.at/books?id=aI8AAwAAQBAJ $\& p g=\mathrm{PA} 1 \& \mathrm{dq}=$ reina+lewis+modesty $\& \mathrm{hl}=\mathrm{de} \& \mathrm{sa}=\mathrm{X}$ \&ved=0ahUKEwjDpKCw6oLKAhWJXBoKHVjeAv

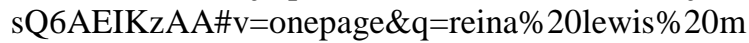
odesty \&f=false

[45] Mela, D. J. (2001). Development and acquisition of food likes. In L. J. Fewer, E. Risvik, and $\mathrm{H}$.
Schifferstein (Eds.), Food, people and society, (9-22). U.K. : Springer.

[46] Mellery-Pratt, R. (2014, May 1). Fashion's missed Muslim market opportunity. Retrieved fromhttp://www.businessoffashion.com/articles/globa 1-currents/fashions-missed-Muslim-opportunity

[47] Meyer, P. (2010). Understanding measurement: reliability. Oxford: Oxford University Press.

[48] Myers, C.A. (2003). Managing brand equity: a look at the impact of attributes. Journal of Product \& Brand Management, 12(1), 39-51.

[49] Netemeyer, R., Krishnan, B., Pullig, C., Wang, G., Yagci, M., Dean, D., Ricks, J. and Wirth, F. (2004). Developing and validating measures of facet of customer-based brand equity. Journal of Business Research, 57(1.2), 209-224.

[50] O'Connor, C. (2016, January 6). Dolce \& Gabbana Launches Hijabs And Abayas As Middle Eastern Luxury Market Hits \$8.7 Billion. Retrieved March 06, 2016, from http://www.forbes.com/sites/clareoconnor/2016/01/06 /dolce-gabbana-launches-hijabs-and-abayas-asmiddle-eastern-luxury-market-hits-8-7billion/\#ce97cde67ddc

[51] Petrilla, M. (2015, July 15). The next big untapped fashion market: Muslim women. Retrieved March 06, 2016, from http://fortune.com/2015/07/15/Muslimwomen-fashion/

[52] Saxena, R. (2009). Marketing management. New Delhi: Tata McGraw-Hill Education.

[53] Schlossberg, M. (2016, January 5). Dolce \& Gabbana is catering to a soon-to-be $\$ 484$ billion market most retailers ignore. Retrieved March 06, 2016, from http://www.businessinsider.de/dolce-and-gabbanadebuts-abaya-line-2016-1?r=US

[54] Silverman, E. (2013). A cultural history of Jewish dress. London: Bloomsbury. Retrieved from https://books.google.at/books?id=clFMAQAAQBAJ $\&$ printsec $=$ frontcover $\& \mathrm{hl}=\mathrm{de} \# \mathrm{v}=$ onepage $\& \mathrm{q} \& \mathrm{f}=$ false

[55] Srinivasan, V. (1979), "Network Models for Estimating Brand-Specific Effects in Multi- Attribute Marketing Models," Management Science, 25(1), 1121.

[56] Strydom, J. (2004). Introduction to marketing ( $3^{\text {rd }}$ Ed.). Cape Town: Juta and Company Ltd.

[57] Swait, Joffre, Erdem, T., Louviere, J. and Dubelaar, C. (1993). The equalization price: a measure of consumer-perceived brand equity. International Journal of Research in Marketing, 10(1), 23-45.

[58] Sweeney, Jillian C. and Geoffrey N. Soutar (2001). Consumer perceived value: the development of a multiple item scale. Journal of Retailing, 77, 203220.

[59] Teodorovic, M. (2015a, July, 10-15). Sustainability as a source for $c \backslash$ equity. Presented at International Academic Conference on Management, Economics and Marketing in Budapest 2015 (IAC-MEM 2015 in Budapest). Czech Republic: Czech Institute of Academic Education, pp. 209-216. 
[60] Teodorovic, M. (2015b, November, 13-14). Building strong brands in a modern sustainable environment. Presented at International Academic Conference on Management, Economics and Marketing in Vienna 2015, Vienna. Czech Republic: Czech Institute of Academic Education, pp. 215-221.

[61] Thomson Reuters (2015). State of the global islamic economy. Dubai: Thomson Reuters in collaboration with DinarStandard ${ }^{\mathrm{TM}}$. Retrieved from http://www.flandersinvestmentandtrade.com/export/si tes/trade/files/news/342150121095027/34215012109 5027_1.pdf

[62] Vazquez, R., Del Rio, A. and Iglesias, V. (2002).Consumer-based brand equity: development and validation of a measurement instrument. Journal of Marketing Management, 18(1/2), 27-48.

[63] Washburn, J.H. and Plank, R.E. (2002). Measuring brand equity: an evaluation of a consumer-based brand equity scale," Journal of Marketing Theory and Practice, 10(1), 46-61.

[64] Weddle Irons, K. \& Springer Mock, M. (2015). If Eve only knew: freeing yourself from Biblical womanhood and becoming all God meant for you to be. Danvers, M.A., USA: Chalice Press. Retrieved from https://books.google.at/books?id=2BdgCgAAQBAJ\& $\mathrm{pg}=\mathrm{PT} 65 \& \mathrm{dq}=\% 22$ modest + clothing $\% 22 \& \mathrm{hl}=\mathrm{de} \& \mathrm{sa}$ $=\mathrm{X} \&$ ved $=0 \mathrm{ahUKEwj}$ smOKj0frJAhUJLhoKHT4eCP YQ6AEIVjAF\#v=onepage\&q=\%22 modest\%20clothi $\mathrm{ng} \% 22 \& \mathrm{f}=$ false

[65] Yoo, B. and Donthu, N. (2001). Developing and validating a multidimensional consumer-based brand equity scale. Journal of Business Research 52, 1-1

[66] Zarantonello, L., Pauwels-Delassus, V. (2016). The Handbook of Brand Management Scales. New York: Routledge. $\quad$ Retrieved from https://books.google.com/books?id=8Q4tCgAAQBA $\mathrm{J} \&$ printsec $=$ frontcover $\& \mathrm{hl}=\mathrm{de} \&$ source $=\mathrm{gbs} \_\mathrm{ge} \_$sum mary_r\&cad $=0 \# \mathrm{v}=$ onepage $\& \mathrm{q} \& \mathrm{f}=$ false

[67] Zeithaml, V. (1988). "Consumer perceptions of price, quality and value: a means end model and synthesis of evidence". Journal of marketing, 52, 2-22.

\section{BIOGRAPHY}

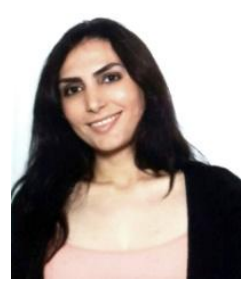

AytakAmininajafi is a student of doctoral studies in the field of International Management at AlpenAdria University of Klagenfurt. She has previously completed her master studies in the same field. Her research interests include international marketing, green marketing, sustainable marketing, inclusive marketing and market development strategies. 